\title{
Teatralidades da linguagem e poesia contemporânea
}

Susana Scramim

UFSC / CNPq

\section{Resumo}

Este artigo pretende discutir os processos de nomeação operados pela escrita contemporânea, especialmente, no trabalho de duas poetas, Paula Glenadel e Nathalie Quintane, em seus livros respectivamente, $A$ fábrica do feminino (2008) e Chaussure (1997). Serão tomados em consideração nesta reflexão os gestos que formulam definiçóes, aplicam atributos, criam tropismos e, simultaneamente, os desconstroem, na medida que colocam o próprio processo de nomeação em xeque nessa experiência de escrita. Com isso, se estabelece uma relação entre voz (querer dizer) e linguagem (ser obrigado a dizer) que implica o enfrentamento de uma das formulaçóes mais radicais da poesia moderna, a saber, reelaborar a relaçáo entre a escrita da poesia - do verso - e a produçáo de um pensamento que se mantenha ético. Esse processo de nomeação e renomeação será denominado aqui de teatralidades da linguagem.

Palavras-chave: Poesia contemporânea; Teatralidades de linguagem; Paula Glenadel; Nathalie Quintane.

\begin{abstract}
This article intends to discuss the naming processes operated by contemporary writing, especially, in the work of two poets, Paula Glenadel and Nathalie Quintane, in their books respectively, A fábrica do feminino (2008) and Chaussure (1997). The gestures that formulate definitions, apply attributes, create tropisms and, at the same time, deconstruct them, shall be taken in this reflection insofar as they put the naming process itself in checkmate in this writing experience. With this, is established a relation between voice (to want to say) and language (to be obliged to say) that implies the confrontation of one of the more radical formulations of modern poetry, to rework the relation between the writing of poetry - of the verse - and the production of a thought that remains ethical. This process of naming and renaming will be called in this article the theatricalities of language.

Mots-clés: Contemporary poetry; Theatricalities of language; Paula Glenadel; Nathalie Quintane.
\end{abstract}


1 MALLARMÉ, Stéphane. Crise de verso, [1897], 2002, p. 202.

2 SISCAR, Marcos. Poesia e crise, 2010, p. 32.
Com uma escrita muito marcada por um desejo de produzir experiências sensíveis e inteligíveis em meio a processos de formulação escrita, a poesia contemporânea responde à exigência de sua tarefa com uma atitude que pode ser lida como uma negaçáo a qualquer tipo de ruptura e, ao mesmo tempo, como a proposição de uma prática escrita cuja função é dar a ver lugares e paisagens criados a partir de cenas (re)tomadas de sua mitologia textual, demonstrando os seus "desgastes". Tal "açáo" retira o enunciado lírico de seu "eterno" tempo presente da enunciação, recolocando-o numa rede anacrônica de temporalidades, portanto, lançando a poesia ao "mundo histórico", no qual o sujeito da enunciação obtém ali uma presença fantasmática. Com isso, na experiência de escrita da poesia a relaçáo entre voz e linguagem coloca em xeque a formulaçáo mais radical da poesia moderna: a relação do verso com a produção do pensamento, da questáo ética e da política. Stéphane Mallarmé, em "Crise de verso", já apontara, em clave histórico-filosófica, que o verso remunera o defeito das línguas e que escrevê-lo era um modo de produzir pensamento moderno, ou seja, pensamento livre. "Les langues imparfaites [...]: penser étant écrire sans accessoiries[..]."

Entende-se aqui a experiência escrita contemporânea como parte da questão do "moderno" na poesia, questão essa que, por sua vez, é compreendida como um problema histórico e cultural que faz com que a literatura esteja em diálogo com outros discursos, inclusive com os discursos que pretendem ocupar-se da formação do sujeito moderno e criador, vale dizer, com a teoria. A questáo do moderno, no entanto, apresenta-se ao mundo marcada por uma atitude artística que leva a poesia a questionar-se a si mesma, cujo resultado é sua própria constituição e, ao mesmo tempo, sua consumação. Segundo Marcos Siscar, a "crise deve ser reconhecida como um traço característico, de natureza ética, da constituição do discurso literário moderno. A poesia está em crise; de certo modo, continua em crise". ${ }^{2} \mathrm{O}$ que é também um modo crítico, portanto, distanciado, de encenar sua existência. Por outro lado, a poesia contemporânea sabe que não pode abdicar do processo de nomear, uma vez que é nele, na prática escrita da nomeaçáo, que ocorre a formulação do "sujeito moderno". E como não pode abdicar para não sucumbir, age por distanciamento de si com ironia: encena sua própria tragédia. Do ponto de vista cultural, também não pode abdicar do diálogo com outras formas de arte e discursos, porque entraria em duelo mortal com aquilo que a constitui enquanto moderna: a crise de sua própria autonomia. Além disso, está ciente de que o processo de criação estética possui a potência de criar mundos, portanto, igualmente não pode abrir mão de um conceito de arte como forma. Entretanto, sem pretender que o produto final se estabilize em uma forma fixa, aposta na concepção de uma arte que busque o "informe" que, segundo proposição de Georges Bataille, não é somente um adjetivo com determinado sentido, mas também é um "termo 
que serve para desqualificar, exigindo geralmente que cada coisa tenha sua forma. $\mathrm{O}$ que designa carece de direito próprio em qualquer sentido e se deixa alastrar em todas as partes como uma aranha ou uma lombriga." ${ }^{3}$ Dito de outra maneira, conforme observou Raúl Antelo, "o contemporâneo nos demonstra que o presente está marcado, desde a sua origem, pelo passado e pelo futuro. Há sempre, em sua emergência, uma lacuna, um hiato, uma ausência. E a história (da literatura ou da arte) não pode ser lida como uma harmoniosa sucessão de presenças, revezando-se e alternando-se entre si, mas como uma incessante reconstrução retrospectiva em que todo signo é presença diferida. $\mathrm{O}$ presente constitui-se assim em relação àquilo que ele não é, nem mesmo como passado ou futuro modificados. ${ }^{34}$ Funcionando como um desdobramento das questões modernas, contudo, sem ilusão alguma de que o resultado desses enfrentamentos modernos venha a produzir estabilizaçôes, a poesia contemporânea constitui-se a si mesma na ambiência do não estabilizado, porém, tateando-o, experimentando-o, vivendo-o entre "encenaçôes" da estabilidade e da "in-estabilidade", entre "mitos próprios" e "desgastes”. Boris Groys, em "The politics of equal aesthetic rights”, propõe que no moderno há uma busca por uma verdade, o pós-moderno operaria desconstruçôes no moderno e o contemporâneo encenaçôes, produzindo cenas de um presente evanescente, importando sempre como sua matéria o aqui-e-agora.

A partir desse argumento, pensa-se aqui a poesia contemporânea como aquela que abandona a prática de um "fazer" artístico, declarando de modo bastante intenso seu "desejo" de produzir arte. Esse desejo se move por encenaçôes da mitologia mesma da literatura. Encenaçôes essas que colocam em evidência os limiares das formulaçôes construídas com base em contradições. Deixa, com isso, de tratá-los como limes/fronteiras e os expóe em carne viva, ou seja, como contradiçôes - que são - não resolvidas. A escrita que resulta desse modo de compreender a si mesma apresenta-se como teatral, uma vez que já não representa nada, não está no lugar de nada, ao contrário, apenas é, sem se preocupar com o elemento que constitui o contraditório, seja ele o referente, seja ele o pensamento abstrato. A poesia contemporânea enfrenta-se com a instabilidade decorrente de uma negação às fronteiras de gênero e da ampliação das concepções de seu próprio fazer artístico estabelecidos de antemão.

\section{Paula Glenadel/Nathalie Quintane: as vidas da traduçáo, ou do pé à dança ${ }^{5}$}

Com o objetivo de pensar os modos pelos quais a prática da encenação produz um distanciamento da escrita da poesia de uma temporalidade
3 BATAILLE, Georges. Informe, [1929], 2003, p. 382.

4 ANTELO, Raúl. A poesia não pensa (ainda), 2016, p. 78.

5 Faço aqui uma referência ao ensaio "Do pé à dança: Chaussure, de Nathalie Quintane" (2003), de Paula Glenadel quando de seu contato com o poema Chaussure. Esse ensaio que promove uma discussão entre feminino, tradução e deslocamento é inspirador para as reflexóes apresentadas neste ensaio. 
puramente enunciativa, detenho-me sobre o caráter performativo da poesia de Paula Glenadel, que inclui o seu trabalho como tradutora e como crítica da linguagem e da literatura. Utilizo o termo "performático" na falta de melhor resultado para esse ato de nomeação. Não quero assumir as implicaçôes do conceito de "procedimento performance", pois compreendo sua concepção como formalista e produtora de "teleologias" e de "teologias" materiais. Tampouco quero valer-me da terminologia dos processos citacionais o que me levaria para o âmbito da retórica e, justamente dela, da imposição normativa, é que eu pretendo me afastar. Justifico minha preferência nesta leitura pelo adjetivo performático, porque ele está mais próximo à minha ideia de ler esse comportamento da linguagem como um "ato" da escrita artística. A ação do texto poético pressupóe um enunciador e um destinatário, no entanto, em minha leitura pressupóe-se que ambos náo têm rosto e que devem receber das máscaras a lufada da enunciaçáo e reagir ao espasmo que os interpela, convocando-os à vida.

Escolhi dois textos para ler essa relação entre o sujeito do enunciado, o sujeito da enunciação e o objeto, operada por essas transposições entre vozes e temporalidades na poesia contemporânea. Entre esses textos acontece uma encenação - são dois corpos desenhados por vozes enunciativas - que os coloca em movimento de mimetização. Entre eles não acontece uma mimese, nem mesmo uma estratégia de citação. Entre eles se institui um lapso, no jogo entre dois, que resulta na abertura - um objeto novo - promovida ali.

Lerei o poema "Teatro" no contraste com a tradução que Glenadel faz de um trecho do poema/livro Chaussure, de Nathalie Quintane, publicado pela editora P.O.L., em 1997, e do ensaio que a poeta carioca escreve sobre esse processo de tradução.

O poema "Teatro" foi publicado em 2008, no livro $A$ fábrica do feminino, pela editora 7 Letras, e está situado na sua segunda parte, "A cidade dos homens". O livro está dividido em três seçôes: "A fábrica do feminino", "A cidade dos homens" e "A cidade fantasma”. Nelas, os lugares são nomeados e, com seus designativos, o jogo entre distância e proximidade entre eles é que se destaca. A fábrica e a cidade designam lugares, enquanto que os homens, o feminino e o fantasma são nomes que doam atributos a seres. O jogo entre o que é relativo ao lugar ou ao ser é apresentado ao leitor na composição mesma do livro. Seres e lugares se encenam num indecidível entre a ideia do que se fabrica e a do que já está dado, entre um "eu" que enuncia uma produção e um objeto resultado da mesma, entre um tempo presente da enunciação, um passado revisitado e um futuro anunciado. Em um pequeno texto que funciona como um exórdio ao livro, é possível ler uma quase encenação de uma razo de trobar de um ato criador que falta: 
O FEMININO É FEITO NUMA FÁBRICA. O masculino é fabricado.

Tudo o que é humano é feito à máquina.

A fábrica é meio antiquada, escura. Contudo, entrevemos uma linha de montagem que produz e reparte androides

femininos e androides masculinos em dois compartimentos distintos.

Saem dali para o mercado, na cidade dos homens, onde catálogos, discursos promocionais já os esperam, onde vão ocupar sempre as mesmas prateleiras.

Ver. Ouvir. Observar essas palavras que há milênios fabricam

o mundo, suas formas. Falar com elas. Habitar a cidade

fantasma.

A fala, fábrica da fábrica. ${ }^{6}$

Se o ato criador "falta", essa razo de trobar poderia ser pensada também como um protocolo de leitura, já que esse gênero textual não está no âmbito tradicional da arte. Trata-se de uma indecidibilidade entre o desejo de enunciar e a constatação de que há uma imposição do que deve ser dito. Essa indecidibilidade é tomada como o "motivo", um desejo de "querer-dizer" e que pode ser compreendido como a ideia de vida do texto, sua vida que ali comparece desde já no impasse entre dizer e repetir. O modo de operar da poesia lírica é o do sujeito que enuncia no presente seu texto, tal operação, quando observa os impasses com os quais se confronta, pôe em cena, simultaneamente, sua própria ascensão e derrocada. É nesse impossível entre o ser e o fazer, entre sentir e falar, entre o fogo e o logos, que se encontra "pitoyable comédie" 7 do teatro da experiência escrita de Paula Glenadel. Nessa elegia cômica a vida se realiza como desejo de ser frente à morte do que já existe, o sujeito se realiza como objeto no movimento de passagem daquilo que está fora do cotidiano subjetivo para dentro e vice-versa. $\mathrm{O}$ movimento acontece entre as palavras - e não entre sujeitos - que são simultaneamente produtoras e produtos do ato de nomeação.

No poema "Teatro", como ressaltei anteriormente, situado em "A cidade dos homens", há uma interpelação no tempo presente da enunciação a um interlocutor que parece ser o destinatário do poema:

Não me venha com segredos. E olha que não acredito em verdades. Mas o teatro do segredo me cansa. Segredos são como carvão em brasa na sola do meu pé. $\mathrm{O}$ teatro da verdade me cansa menos. Verdades são como a sola do sapato que cobre a sola do meu pé. Você só pensa que me dói a brasa na sola do pé, mas não vê a dor da brasa entre a sola do sapato e a sola do pé. Pulo, e logo penso: o logos, o fogo. ${ }^{8}$
6 GLENADEL, Paula. A fábrica do feminino, 2008, p. 7.

7 O termo é de Colette Peignot ou Laure. Ela pertenceu ao círculo dos intelectuais que orbitavam em torno do Collège de Sociologie. O caráter ativo de sua escrita literária produziu uma profunda busca existencial. Seu intransigente e angustiado modo de vida e de escrita abriram pungências as quais, juntamente com o trablaho de Georges Bataille, resultaram em análises referentes a formas de vida frente à castração corporal e mental provocadas pelo excesso de cientificismo e controle das emoçôes subjetivas. Trata-se de uma escrita na qual o político está proposto de modo simultâneo ao pathos trágico, vale ressaltar que o aspecto trágico de sua escrita esteve submetido ao uso de máscaras e elementos protéticos no sujeito, diante das paixóes e do desejo de comunicabilidade de sua obra, além disso, sua busca pela soberania do sujeito incluía a consideração do sagrado - em seus aspectos de vida coletiva - nos elementos cotidianos da vida comum. Ainda que os movimentos do sagrado conduzam a um deslocamento para fora do cotidiano, é justamente a partir dos acontecimentos cotidianos que esse movimento é deflagrado. O acontecimento do sagrado requer uma vida com os outros e será nesse sentido que a "corrida de toros" será nomeada por Laure como o momento no qual se reestabelece o contato com o sagrado, justamente porque a morte ali é sentida no espetáculo coletivo e, simultaneamente, de modo ficcional individual, configurando o que ela denominou como "pitoyable comédie”, como lastimosa comédia. Onde se lê "sagrado", se deve ler também mundo arcaico e coletivo e que foi, consequentemente, desprezado pelos valores racionalistas modernos. Cf. PEIGNOT, Collete, Lo sagrado. Laure. Notas de Georges Bataille y Michel Leiris. Traducción de Julio Azscoaga, 1. Edición. Ciudad de Buenos Aires: Hekht libros. E também em Idem, Écrits de Laure. Texts établi par J. Peignot et le Collectif Change. Paris : Pauvert, 1997. 
8 Ibidem, p. 40.

\section{O conceito de "denegação"} inclui uma ideia de autoproteção na qual o sujeito recusa-se no presente a reconhecer algo como sendo seu, mas que em um momento anterior fora "permitido" conscientemente.

10 Vale lembrar que a noção de "salto", der Sprung, que se encontram na base da reflexão sobre a temporalidade histórica em Walter Benjamin, pode também ser lida na imagem dos "pulos" do poema de Glenadel.

Em sua reflexáo sobre o conceito de "origem", Walter Benjamin esteve atento ao étimo que compunha o termo der Ursprung em alemão, concebendo com isso uma definição de origem que envolvia um salto para fora da linearidade, não escamoteando as tensóes inerentes às reflexóes que dizem respeito ao movimento do tempo. Cf. BENJAMIN, Walter. Origem do drama barroco alemão, 1984, p. 67-69.
A princípio, um "eu" interpela um "tu" confrontando-o com uma discussão que denega o uso das palavras sob o primado do sentido escondido, do "segredo", mas não para afirmar seu contrário, a limpidez do sentido explícito, e sim para confrontá-lo com o problema da "verdade" que náo é o antônimo de "segredo". ${ }^{9}$ Nessa deriva, o lugar entre verdade e segredo torna-se impossível de ser geometrizado, desdobrando-se nele outra impossibilidade: a da distinção entre o fato e sua encenação, entre um sujeito e sua personae, entre um objeto e sua projeção e, por paralelismo com o conjunto do livro, entre "o homem" e "o feminino". No poema de Paula Glenadel, essa série construída pela lógica do desdobramento paralelístico é cogitada a partir de uma experiência ocorrida na extremidade do corpo do sujeito da enunciação: o pé que dança com uma pedra dentro do sapato e transporta sua dor para dentro dessa experiência. O pé que, como lugar extremo do contato com o mundo, produz a dor justamente no espaço intermediário, no espaço do impossível. Entre logos e fogo, entre pensamento e corpo, entre discurso e emoçâo, entre língua articulada e grito, entre o relato e a expressão subjetiva da dor, o poema, em clave irônico-trágica, relaciona sua performance com os pulos que são produzidos pela dor que está no discurso. O pé métrico do poema - que é som antes de ser sentido - e sua vestimenta que é sua estância, seio no qual toda a razão do poema repousa, são associados ao impasse do poema que se faz mediante outra encenação do impossível, um ser entre: o espetáculo sonoro imagético e comunicador de sua própria premissa ou ser uma peça de saber. Constrói-se, desse modo, um poderoso processo de deslocamento que sopra da tormenta que atinge todo o sentido histórico da língua, proporcionado por suas corrosivas situaçóes da fala, e retorna ao agente mesmo dos deslocamentos para um novo uso, um novo cataclismo. O sujeito da enunciação sai de si, é e não é ato enunciativo, descaracterizando o sujeito "lírico", que entra na temporalidade anacrônica do histórico ao "pular" entre "logos" e "fogo". ${ }^{10}$ O poema vai lentamente apontando os deslocamentos de que são feitas suas frases. Esses deslocamentos atuam como "tormentas" que atingem todo o sentido histórico da língua, em suas corrosivas situaçôes de fala, promovendo um novo "uso" deslocado.

\section{Um sapateado aos "pulos"}

Um desses "pulos" é operado pelo poema de Paula Glenadel mediante a tradução. Trata-se da traduçáo que a poeta carioca fez de um fragmento do poema/livro Chaussure, de Nathalie Quintane, em 2003, e de um estudo reflexivo sobre essa tradução para uma participação sua em um evento coordenado por Flora Süssekind, Tânia Dias e Carlito Azevedo, "Vozes femininas. Gênero, mediaçôes e prática da escrita”, que aconteceu em maio de 
2001, sendo os textos ali apresentados reunidos e publicados pela 7 Letras com título homônimo. ${ }^{11}$

Quando penso na palavra sapato, isto é, quando a digo, seja, ou não, articulando-a na boca, ela me chega, por exemplo, associada a um par de sapatos (mocassins amarelos) que eu tinha quando criança, que chamaram, nessa época, a atenção de meus colegas (que ideia, usar sapatos amarelos), que logo os compararam a biscoitos recheados de laranja que distribuíam nas cantinas; ou associada ao interesse exacerbado que uma de minhas amigas dedica aos sapatos, acumulando as caixas, economizando meses para a compra de um par; ou à única vez em que um vendedor me deu características técnicas, e termos, que me abriram um mundo táo complexo quanto o do motor de quatro tempos; ou ainda a esse exercício de dicção, no qual na verdade se trata das meias de uma arquiduquesa [chaussettes d'une archiduchesse], e não de seus sapatos; ou à lista dos nomes de sapatos, e, de fato, ao texto-sapato, ao qual me remete atualmente a palavra sapato, que náo posso ler nem ouvir sem pensar no estado do texto em curso, nos meios de corrigi-lo ou de aumentá-lo; por isso é provável que a palavra sapato continue a evocar para mim por muito tempo este texto. ${ }^{12}$
11 Posteriormente, em 2012, Paula Glenadel incluiu essa tradução na antologia que organizou em língua portuguesa, juntamente com um estudo dos poemas de Nathalie Quintane para compor a Ciranda de poesia, publicada pela Editora da UERJ.

12 Nathalie Quintane. Sapato, apud GLENADEL, Paula, 2012, p. 60.

13 Idem, "Do pé à dança: Chaussure, de Nathalie Quintane", 2003, p. 133.

Sendo a tradução a probabilidade mais próxima do diferimento, uma deriva não resolvida entre línguas, e a denegação de uma como o original da outra, abre-se para o poema "Teatro", de Glenadel, a possibilidade de encenar o ato enunciativo do sujeito "lírico" sob outra forma, isto é, a partir de outra personae textual. No poema de Quintane, sugere-se que a forma do conteúdo - o pé do sapato - terá - por questóes de impasse metodológico - a forma da forma - o sapato. O sapato tem a forma do pé e o pé adquire a forma da coisa. Paula Glenadel está atenta para o jogo instaurado pela linguagem do tradutor de poesia que tanto molda quanto é moldado pelo texto com o qual lida. E, enquanto escreve sua análise do poema de Quintane, vai destacando os seguintes trechos do mesmo:

A forma do pé inscreve-se na própria forma do sapato - ou, a forma do sapato é a imagem da do pé. ${ }^{13}$

Ou, como é possível ver a seguir, a coisa é vista na extensão/deslocamento dela em outra coisa: 
14 Ibidem, p. 134.

15 GLENADEL, Paula. A fábrica

do feminino, 2008, p. 7.
O pé, como qualquer outra parte do corpo, é afetado por aquilo com que ele entra em contato - assim quando se anda muito tempo sem sapato, a planta dos pés acaba por ter a consistência de uma sola. ${ }^{14}$

Um outro "pulo" lança o olhar reflexivo para os usos possíveis do "objeto" e do "sujeito", situando-os em um lugar nem sempre passível de geometria nem tampouco hierarquizável, ou seja, situando-se entre "eu" e "mundo" quando se concentra no tratamento dado à palavra "sapato". Desconstruir a visão ingênua instaurada pela naturalização das relaçóes analógicas da linguagem, é o problema dos dois poemas em questão, tanto em Chaussure, quanto em "Teatro". O termo sapato não é tomado pelo seu conteúdo referencial, pois não há pretensão alguma em retomar uma concepção de linguagem que mantenha ingenuamente a oposição entre aparência e verdade, entre nome e coisa. Ele é tomado em sua deriva, em seu deslocamento infinito. Disso decorre a escolha por um objeto que em si já é um fetiche. E é sabido que o fetiche se caracteriza por ser puro deslocamento de sentido, nada do que é é, trata-se sempre de outra coisa. E nada mais radical do que operar o fetichismo com um fetiche, nada melhor que encenar essa operação.

Um terceiro "deslocamento" é o que diz respeito à diferença sexual, que não deixa de ser resultado também de um ato de questionar a relação naturalizada entre linguagem e mundo. O que ocorre é outro tipo de denegação, não há o que se procurar quando se está simultaneamente diante de uma ausência e uma presença, de um sentido consentido e outro não. $\mathrm{O}$ que se evidencia é o caráter discursivo de toda diferença e a necessidade de compreendê-la incessantemente como deslocamento infinito. No caso do livro $A$ fábrica do feminino, a denegação aparece na operação da máquina fetichista e ajuda a desmontar uma teoria falo-logo-cêntrica de que o feminino seria definido na cultura ocidental por uma falta frente a uma presença definidora do masculino. Como vimos no protocolo de leitura de $A$ fábrica, a fábrica é a fala, que funda uma cultura do não refletido, do não analisado, uma cultura na qual os vencedores são os que falam mais alto

Ver. Ouvir. Observar essas palavras que há milênios fabricam o mundo, suas formas. Falar com elas. Habitar a cidade fantasma.

A fala, a fábrica da fábrica. ${ }^{15}$

A tradutora e estudiosa do poema Chaussure observa que há um jogo instaurado com a homofonia produzida pela vocalização da palavra chaussu- 
re na língua francesa, essa vocalização cria uma zona de indiferenciação entre o sentido de sapato e o de coisa segura, dado pela associação de chaussure com chose-sûre. Desse modo, o jogo analógico, ao mesmo tempo que define e estanca, cria igualmente a possibilidade de imprecisão e deslocamento do sentido. $\mathrm{O}$ jogo analógico funciona ele próprio com a materialização em forma de vocábulo do efeito "desmaterializante" causado pelo fetiche, ou seja, o sapato é ele próprio um fetiche da sociedade moderna não podendo prestar-se, de maneira alguma, a funcionar como coisa segura (chose-sûre). Tal exposição - que é um tipo de teatralização dos modos de atuar da linguagem - expõe o impasse da dicotomia entre forma e fundo que é definida como uma presença referendada por um conteúdo. No deslocamento desse impasse pelo poema "Teatro", a linguagem do poema revisita "clichês" os quais têm que agir, questionando a relação ao modo de chose-sûre entre palavras e coisas. Na relação linguagem-clichê, a verdade, o masculino, vem associada à ideia de uma presença de um conteúdo explícito e determinado, e o feminino, ao contrário, se define em detrimento de algo que não pode ser definido, pois é mera aparência ou ausência de conteúdo. No poema "Teatro", o segredo, em sua relação também tomada como lugar-comum, compreendido como antagonista da ideia de verdade, cansa e faz sofrer mais intensamente a linguagem no teatro do poema.

[...] acredito em verdades. Mas o teatro do segredo me cansa. Segredos são como carvão em brasa na sola do meu pé. O teatro da verdade me cansa menos. ${ }^{16}$
16 Ibidem, p. 40.

17 AGAMBEN, Giorgio. Estâncias, 2007, p. 60 .

No entanto, não é simples produzir aos "saltos" uma crítica a essa relação que distingue em dois polos opostos as instâncias da verdade e sua aparência, ou ainda, entre o que é segredo e o que é explícito, entre fundo e forma ou entre a diferença sexual. Não propriamente sobre a diferença sexual, mas a partir da reflexão de sua operação na língua, isto é, sobre a obscuridade da construçáo analógica na poesia, Giorgio Agamben, em "Freud ou o objeto ausente", de seu livro de 1977, Estâncias, escreve:

Prova-se assim, que não se trata apenas de uma analogia superficial pelo fato de que a substituição metonímica não se esgota na pura e simples substituiçáo de um termo por outro: o termo substituído é, ao contrário, simultaneamente negado e evocado pelo substituto com um procedimento cuja ambiguidade lembra de perto a Verleugnung (denegação) freudiana, e é justamente dessa espécie de "referência negativa" de onde nasce o particular potencial poético de que fica investida a palavra. ${ }^{17}$ 
18 GLENADEL, Paula. Nathalie Quintane. Ciranda de poesia, 2012, p. 9.
O fetiche é uma substituição, no entanto, não se trata de substituir algo no qual alguma coisa da primeira é evocada. O fetichista cria um outro campo, um outro relato. E com isso instala-se à margem da metafísica. Não está interessado na verdade da coisa, nem no seu "segredo". Está ali escondido para, em algum momento, surgir à superfície, e não para ser revelado. Não é a revelação a exigência dessa linguagem. O fetichista se situa na margem dessa verdade. Nesse sentido, ele é revolucionário, já que é a matriz originária de todas as perversóes. Estas, por sua vez, instauram um lugar de contestação da normalidade e do conservadorismo. Entretanto, sua posição é de "borda" e, com isso, vai tomando de empréstimo o que está ao redor da imagem sexual da máe/feminino com a finalidade de chamar a atenção, atrair e fixar o olhar mediante uma ação de abordagem, de lateralidade, "a-bord-agem", ou ainda, tomar um bordo sem, contudo, desejar ou permanecer alinhado.

\section{Do mundo. Do sujeito}

É nesse sentido que os processos de deslocamento e suas próteses interessam mais nesse tipo de reflexão sobre a linguagem do que saber sobre o primeiro elemento que possivelmente as desencadeou. Lembrando aqui que esse deslocamento de sentidos em seu processo de abordagem também tem a potência de quitar-lhe ao sentido suas amarras, seu cadeado, liberando-o para a viagem, a experiência benjaminiana (die Erfahrung). As vestimentas, os sapatos, a maquilagem e a linguagem são pensadas nessa experiência não como objetos de ornamento, mas, antes, enquanto a linguagem mesma tomada como ornamento em si; isso caracteriza um modo de ser e de existir da poesia que envolve a operação da linguagem em deslocamento. Portanto, como escreveu Paula Glenadel na introdução/protocolo ao seu livro sobre Quintane, da Ciranda de Poesia:

Assim, este começo do texto deveria explicitar, já está explicitando, algumas coisas bastante óbvias, sobre o que ele é, sobre o que ele não é. A primeira coisa é que se trata aqui de um texto crítico, e não literário ou poético, de inspiração "desconstrucionista”, porque ele professa como protocolo um estranhamento de seus protocolos e busca se colocar numa distância para consigo mesmo - traço, contudo, também compartilhado pela literatura e pela poesia em certo viés moderno e contemporâneo; estendendo o olhar um pouco mais longe, pode-se lembrar que a chamada "desconstrução" (ou desconstruçôes, pois há mais de uma, sendo identificáveis, pelo menos, a de Friedrich Nietzsche, a de Martin Heidegger, a de Jacques Derrida) corresponde ao (re)interesse dos filósofos pela literatura e pela poesia. ${ }^{18}$ 
Se a linguagem é tomada como o próprio ornamento em si - e como eu também gostaria de destacar, como um modo de teatralizar e fazer aparecer, já que o teatro é o lugar da aparição por excelência - quais são as estratégias para chamar a atenção para o "si" da linguagem? Como despertar o seu potencial mais revolucionário? O que está em jogo na relação forma e conteúdo?

Sarah Kofman, em Lectures de Derrida - reivindicada por Glenadel para sua meditação sobre a língua que se inventa na escrita do livro Chaussure fala de uma oscilação entre a forma e o fundo, entre verdade e aparência.

A oscilação fetichista permite, ao contrário, fazer mover as categorias metafísicas, fazer oscilar entre uma dialética e uma lógica totalmente diferente, a do indecidível, ela acarreta necessariamente uma especulação que oscila entre um gesto de domínio da oscilação e um gesto que abala e solicita todas as oposições, arrastando em sua deriva, entre outros, a oposição fetiche/ não fetiche, substituto/coisa mesma, masculino/feminino, em proveito de uma generalização dos termos mais desvalorizados pela hierarquia metafísica: o fetichismo, o substituto, o Ersatz, a suplementaridade e, porque o feminino é caracterizado pela oscilação, em proveito também do feminino. ${ }^{19}$

Kofman que é autora de um estudo ${ }^{20}$ sobre a metáfora a partir da filosofia de Nietzsche, reivindica um "uso" da língua no qual o primado da "individualidade", ou ainda da "propriedade", seja desvestido de seu "uso" conservador.

Ao cancelar a oposiçáo dada como natural entre metáfora e conceito para dar-lhe nada além de uma diferença de grau em comparação a seu caráter metafórico (pelo menos o metafórico não é um conceito, mas uma metáfora), Nietzsche instaura um tipo de filosofia que usa deliberadamente a metáfora, arriscando ser confundida com a poesia. Entretanto, para Nietzsche essa confusão não seria deplorável: a oposiçấo entre filosofia e poesia é metafísica e repousa sobre uma divisão entre real e imaginário e em uma separação das faculdades: a filosofia é uma forma de poesia. $^{21}$

Ao recuperar de Nietzsche a observação do comportamento não original ou próprio dos conceitos, tomados como verdades sobre as coisas, desvestindo-os a partir de operaçóes de deslocamento de sentido, Kofman questiona o princípio que ordena historicamente os vetores de deslocamento, vale dizer, da essência das coisas em direção à linguagem. A filósofa francesa deseja oferecer potência desconstrutiva à operação analógica, reco-
19 KOFMAN, Sara. Lectures de Derrida apud GLENADEL, Paula. "Do pé à dança: Chaussure, de Nathalie Quintane", 2003, p. 133.

20 Uma versão resumida do livro de Sara Kofman, Nietzsche et la métaphore (1972), foi publicada sob a forma de artigo na revista Poétique, no número 5 do ano de 1971 , ressalte-se aqui que neste número da revista, que tem o título de Réthorique et philosophie, foram publicados os textos de Jacques Derrida, "La Mythologie Blanche", sobre os usos da metáfora no texto filosófico, e um dossiê de Nietzsche "Réthorique et langage", sob a responsabilidade de Jean-Luc Nancy e Philippe Lacoue-Labarthe.

21 KOFMAN, Sara. Nietzsche et la métaphore, 1971, p. 80-81. 
22 AGAMBEN, Giorgio. Estâncias, 2008, p. 60-61. locando a discussão nos termos de uma não precedência de uma origem em relação a uma destinação, especialmente no que diz respeito ao debate entre poesia e filosofia, ou ainda, entre política e arte.

Num outro contexto, mas não menos longe deste aqui em questão, Agamben, no já citado livro de 1977, Estâncias, fala de ambiguidades entre o fragmento e o todo, entre a essência das coisas, suas derivas e sua interdependência constitutiva.

O caráter fetichista do fenômeno torna-se evidente no tipo particular de procedimento metonímico que, desde a época em que Vasari e Condivi apresentaram o seu primeiro reconhecimento crítico relativo às esculturas "incompletas" de Miguel Angelo, se converteu em instrumento estilístico essencial da arte moderna: o não-acabado. Gilpin, que impulsionou de tal forma o gosto pré-romântico pelo inacabado a ponto de propor a destruiçáo da metade das vilas de Palladio, a fim de as transformarem em ruinas artificiais, já se havia dado conta de que o que ele denominava "laconismo do gênio" consistia exatamente em "dar uma parte pelo todo". Schlegel, a quem se deve a profética afirmação de que "muitas obras dos antigos transformaram-se em fragmentos, enquanto muitas obras dos modernos o são ao nascerem", pensava, como Novalis, que toda obra acabada estivesse necessariamente sujeita a um limite de que só o fragmento poderia escapar. É supérfluo lembrar que, nesse sentido, quase todos os poemas modernos, de Mallarmé em diante, são fragmentos, porquanto remetem a algo (o poema absoluto) que nunca pode ser evocado integralmente, mas só se torna presente mediante a sua negação. A diferença em relação à metonímia linguística normal reside aqui no fato de o objeto substituído (o "todo" a que o fragmento remete) é, como o pênis materno, inexistente ou já não existente, e assim o não-acabado se revela como um perfeito e pontual pendant da Verleugnung fetichista. ${ }^{22}$

O pendant aqui indicaria a singularidade de cada elemento na equação, apregoando, contudo, a sua dependência mútua, isto é, existem por si apenas enquanto são pares simétricos, mas que se encontram suspensos. No entanto, a operaçáo do sentido movimenta-se por deslocamentos, "pulos". Isso os une e promove a deriva da verdade e a consequente des-substantivação do próprio, de sua essência, promovendo também sua "limpeza" conceitual para abrir-se a outras tentativas de verdade. Ao colocar em evidência o processo de "fetichizaçáo" inerente à linguagem, o poema "Teatro", de Paula Glenadel, e Chaussure, de Nathalie Quintane, póem em "cena” aquilo que está envolvido no enfrentamento do sujeito com o mundo e seu atravessamento pela linguagem. Como podemos observar nesses versos de Quintane: 
Quando penso na palavra sapato, isto é, quando a digo, seja, ou não, articulando-a na boca, ela me chega, por exemplo, associada a $[. . .]^{23}$

E também nos seguintes versos de Glenadel:
23 QUINTANE, Nathalie. Chassure, 2012, p. 60.

24 GLENADEL, Paula. A fábrica do feminino, p. 40.

\begin{abstract}
Verdades são como a sola do sapato que cobre a sola do meu pé. Você só pensa que me dói a brasa na sola do pé, mas não vê a dor da brasa entre a sola do sapato e a sola do pé. ${ }^{24}$
\end{abstract}

A linguagem pode definir o sentido das coisas do mundo em duas vertentes: a primeira, encontrando seu equivalente ideal metafísico no mundo dos conteúdos não materiais, porém, racionais; a segunda, concentrando-se nos valores materiais do signo, transformando-o em coisa, isto é, em uma palavra que designa uma imagem de uma verdade objetiva. Isto é aquilo. Isto é como aquilo. No segundo modo, operaria como o pensamento analógico racional e, portanto, também envolveria uma concepção metafísica da vida. Haveria algum procedimento de simbolização que escape à metafísica? Esta análise desejou demonstrar que o processo de fetichização teria em princípio a potência para tal operaçáo de deslocamento do sentido tanto material quanto idealista, levando-os ao limite. Para isso acontecer, é necessário um ponto de vista não convencional e que opere a partir dos "clichês". Requer uma constatação de que todo objeto é indissociável de um texto-objeto, de que o mundo é um pontual pendant do que se fala e do que se escreve dele, de sua denegação.

\section{Referências}

AGAMBEN, Giorgio. Estâncias. A palavra e o fantasma na cultura ocidental. Tradução de Selvino Assman. Belo Horizonte: Ed. UFMG, 2007.

ANTELO, Raúl. A poesia não pensa (ainda). In: SCRAMIM, Susana (Org.) Alteridades na poesia contemporânea. Riscos, aberturas, sobrevivências. São Paulo: Iluminuras. 2016.

BENJAMIN, Walter. Origem do drama barroco alemão. Tradução de Sergio Paulo Rouanet. São Paulo: Ed. Brasiliense, 1984.

GLENADEL, Paula. Nathalie Quintane. Ciranda de Poesia. Rio de Janeiro: Ed. UERJ, 2012. 
GLENADEL, Paula. A fábrica do feminino. Rio de Janeiro: 7 Letras, 2008.

GLENADEL, Paula. Do pé à dança: Chaussure, de Nathalie Quintane. In: SÜSSEKIND, Flora; DIAS, Tânia; AZEVEDO, Carlito. Vozes femininas. Gênero, mediaçôes e práticas de escrita. Rio de Janeiro: 7Letras: Fundação Casa Rui Barbosa, 2003.

BATAIILE, Georges. La conjuración sagrada: ensayos 1929-1939. Buenos Aires: Adriana Hidalgo, 2003.

GROYS, Boris. The politics of equal aesthetic rights. In: ALLIEZ, Éric; OSBORNE, Peter. Sphers of Action: Art and Politics. Massachusetts, Cambridge: Mit Press, 2013.

KOFMAN, Sara. Lectures de Derrida. Paris: Editions Galilée, 1984.

KOFMAN, Sara. Nietzsche et la métaphore. 2. éd. rev. et corr. Paris: Editions Galilée, 1983

KOFMAN, Sara. Nietzsche et la métaphore. Poétique, v. 5, 1971, Éditions du Seuil, Paris, p. 77-98.

MALLARMÉ, Stéphane. Divagaçôes. Tradução de Fernando Scheibe. Florianópolis: Ed. UFSC, 2002.

MURENA, Hector. La metáfora y lo sagrado. Buenos Aires: El cuenco de la Plata, 2012.

PEIGNOT, Collete. Lo sagrado. Laure. Notas de Georges Bataille y Michel Leiris. Traducción de Julio Azscoaga, 1. Edición. Ciudad de Buenos Aires: Hekht libros.

PEIGNOT, Collete. Écrits de Laure. Texts établi par J. Peignot et le Collectif Change. Paris : Pauvert, 1997.

SISCAR, Marcos. Poesia e crise: ensaios sobre a "crise da poesia" como topos da modernidade. Campinas: Ed. Unicamp. 2010.

Submissão: 02/10/2018

Aceite: 20/10/2018

https://doi.org/10.5007/2176-8552.2018n25p17 